\title{
T-Bar Clasp-Retained Removable Partial Denture as an Alternative to Implant-Based Prosthetic Treatment
}

\author{
Osvaldo Luiz BEZZON \\ Mariane GONÇALVES \\ Valéria Oliveira PAGNANO \\ Department of Dental Materials and Prosthodontics, Dental School of Ribeirão Preto, \\ University of São Paulo, Ribeirão Preto, SP, Brazil
}

\begin{abstract}
This article reports the case of a 55-year-old female patient who presented with unsatisfactory temporary crowns in the right mandibular premolars and molars, and a premolar-to-molar fixed partial denture in the left side. The clinical and radiographic examinations revealed a fracture of the left first premolar that was a retainer of the fixed partial denture and required extraction. Initially, the acrylic resin crowns were replaced by new ones, and a provisional RPD was made using acrylic resin and orthodontic wire clasps to resolve the problem arising from the loss of the fixed partial denture. Considering the patient's high esthetic demands, the treatment options for the definitive prosthetic treatment were discussed with her and rehabilitation with implant-supported dentures was proposed because the clinical conditions of the residual alveolar ridge were suitable for implant installation, and the patient's general health was excellent. However, the patient did not agree because she knew of a failed case of implant-retained denture in a diabetic individual and was concerned. The patient was fully informed that implant installation was the best indication for her case, but the arguments were not sufficient to change her decision. The treatment possibilities were presented and the patient opted for a claspretained removable partial denture (RPD) associated with the placement of crowns in the pillar teeth. The temporary RPD was replaced by the definitive RPD constructed subsequently. Although RPD was not the first choice, satisfactory esthetic and functional outcomes were achieved, overcaming the patient's expectations. This case report illustrates that the dentist must be prepared to deal with situations where, for reasons that cannot be managed, the patient does not accept the treatment considered as the most indicated for his/ her case. Alternatives must be proposed and the functional and esthetic requirements must be fulfilled in the best possible manner.
\end{abstract}

Key Words: removable partial denture, prosthetic planning, free end saddle.

\section{INTRODUCTION}

Despite all efforts to overcome the esthetic and functional problems related to the construction of removable partial dentures (RPDs) (1-7), these prostheses are not the first choice of a large number of patients due not only to esthetic impairments, but also to the discomfort related to their base extension (8). Clinical situations requiring the replacement of multiple teeth or bilateral posterior edentulous spaces are the classical indication for RPDs. However, when anterior teeth must be used as retainers for an RPD, it is a great challenge to achieve an esthetic outcome with circular or T-bar clasps (9). In view of these shortcomings, many patients are adverse to RPD treatments $(10,11)$.

Implant-supported dentures have presented as a successful treatment option in oral rehabilitation, offering improved esthetics and biomechanical advantages. The increase in their clinical indications has determined a considerable reduction in the use of RPDs. Nevertheless, some patients do not accept prosthetic treatments based on implant systems alleging health, financial, psychological or anatomical hindrances $(12,13)$.

When, for whatever reason, RPD is the treatment of choice, the dentist must try to meet as close as possible the patient's functional needs and esthetic 
expectations in the same way as it would be done in the case of a more sophisticated denture. Therefore, RPD planning should consider the benefits of using adhesives for attachment and bonding or composite resin for preparation of strategic areas on pillar teeth, irrespective of the wear process (14-17). The placement of a provisional denture, which is part of more sophisticated treatments (18), should also be used between the initial phase of extracting holpless teeth and the final case. In addition to providing a short-term esthetic improvement (19), the fabrication of a provisional denture can contribute to the treatment planning by revealing important details for the definitive denture.

This article presents a clinical situation where the indication of a provisional RPD with unilateral free end resolved the immediate esthetic problem and was essen- tial for the definitive prosthetic planning. The treatment was conducted according to esthetic and biomechanical principles and proved to be the best possible option for a patient that refused implant-supported denture.

\section{CASE REPORT}

A 55-year-old female patient presented with great concern about the perspective of using a RPD after the loss of a posterior tooth that supported a fixed partial denture (FPD) in the left mandible. The FPD comprised retainer and a pontic in cantilever sectioned from the posterior retainer that had been extracted. Extraction had occurred a few months earlier, causing the FPD dislodgement from the supporting teeth.

The clinical examination revealed the presence of
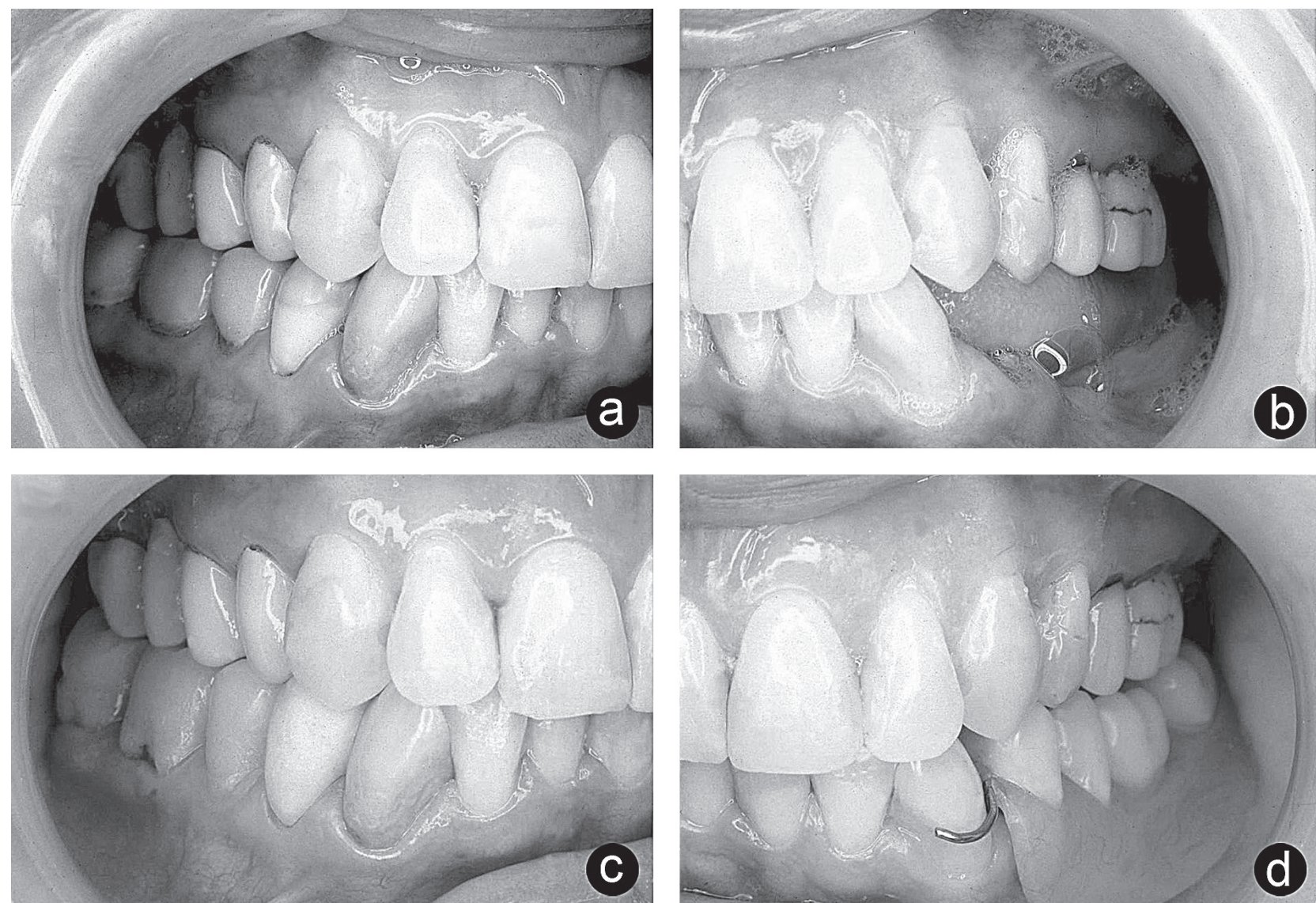

Figure 1. Clinical photographs. A= Unsatisfactory provisional acrylic resin crowns on the right side at the patient arrival; $B=$ Left first premolar with a longitudinal root fracture at the patient arrival; $\mathrm{C}=\mathrm{New}$ provisional acrylic resin crowns placed on the right side; $\mathrm{D}=$ Temporary removable partial denture placed before extraction of the fractured mandibular left premolar. 
unsatisfactory provisional acrylic resin crowns on the mandibular right premolars and molars. On the left side, the mandibular first premolar that supported the FPD was fractured longitudinally and also required extraction (Fig.1 A and 1B). Initially, the acrylic resin crowns were replaced by new ones, and a provisional RPD was made using acrylic resin and orthodontic wire clasps, which were installed before premolar extraction. This procedure essentially resolved the problem caused by the loss of the FPD, but the patient complained about the visible clasps and the base color of the provisional RPD (Fig. $1 \mathrm{C}$ and $1 \mathrm{D})$, revealing high esthetic expectations.

The treatment options were discussed with the patient and rehabilitation with implant-supported dentures was proposed as the best option due to the clinical conditions of the residual alveolar ridge were suitable for implant installation, and her general health was excellent.
However, the patient did not agree because she knew a failed case of implant-retained denture in a diabetic individual and was concerned. The patient was fully informed that implant installation was the best indication for her case, but the arguments were not sufficient to change her decision. Other possibilities were discussed and the patient only agreed with the placement of a RPD, but demanded that it should be retained by attachments that were not exposed on smiling.

The severe crowding between the left canine and the lateral incisor, that was harmonious to a similar condition on right side, caused difficulties for crown preparation in terms of the attachment arrangement and even for the trial of extra-coronal attachment fixation through an adhesive retainer (Fig. 2). Since the patient refused implant placement, but agreed with a RPD, the treatment proposed included the fabrication of metal-
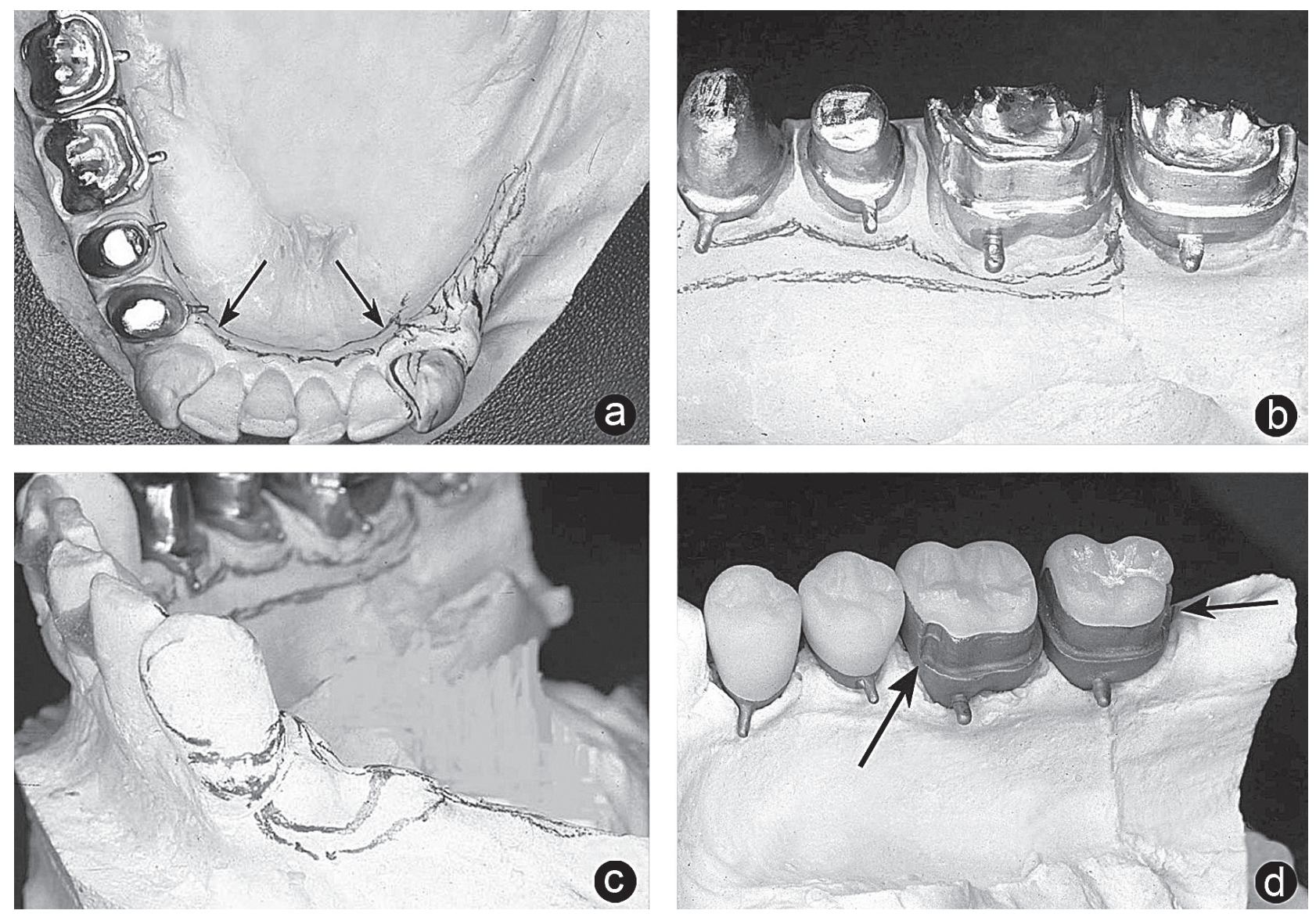

Figure 2. A= Symmetric crowding of canines and lateral incisors; B= Milled metal-ceramic crowns for the RPD retainer; $C=$ Esthetic planning of T-bar clasp; $\mathrm{D}=$ Prepared retentions in the metallic portion of metal-ceramic crowns for the RPD clasp. 


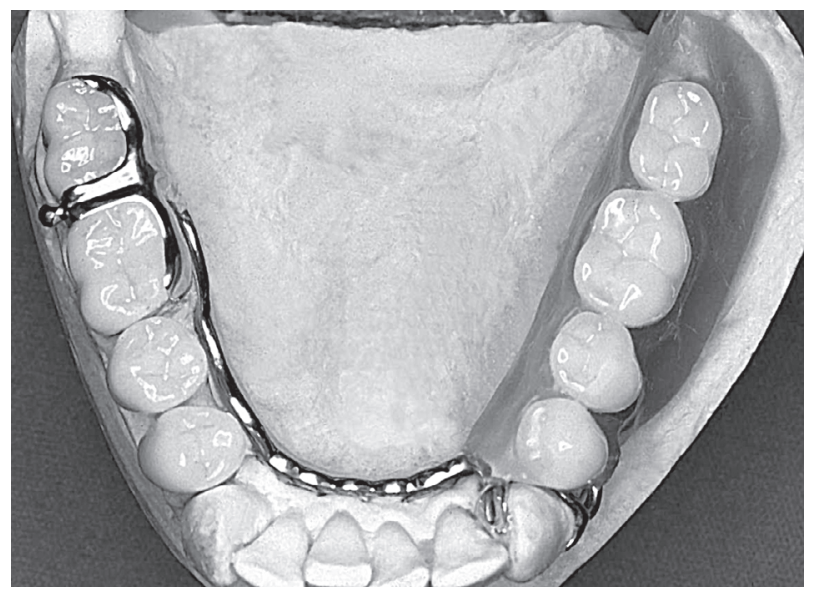

Figure 3. Occlusal view of the definitive mandibular T-bar claspretained RPD. No indirect retainer was used to neutralize the fulcrum line between the geminated retainers from the right side and the left canine. ceramic crowns on the right side milled for arrangement of geminated retainers for the RPD, and the use of canine clasp positioned strategically to achieve an esthetic result (Fig. 2). The metal-ceramic crown preparations to receive the RPD included the preparation of long guide planes on the lingual and proximal surfaces with retentive niches next to the occlusal edge of guide planes on the mesial surface of the first molar and on the distal side of the second molar (Fig. 2D). A cingulum rest was prepared on the lingual surface of the canine with composite resin and a retentive area was made on the buccal surface in order to hide the elevation of the clasp, which could occur if the mesiobuccal surface was used, as had occurred with the provisional denture.

In order to make the denture as comfortable as possible, no indirect retainer (20) was introduced in an
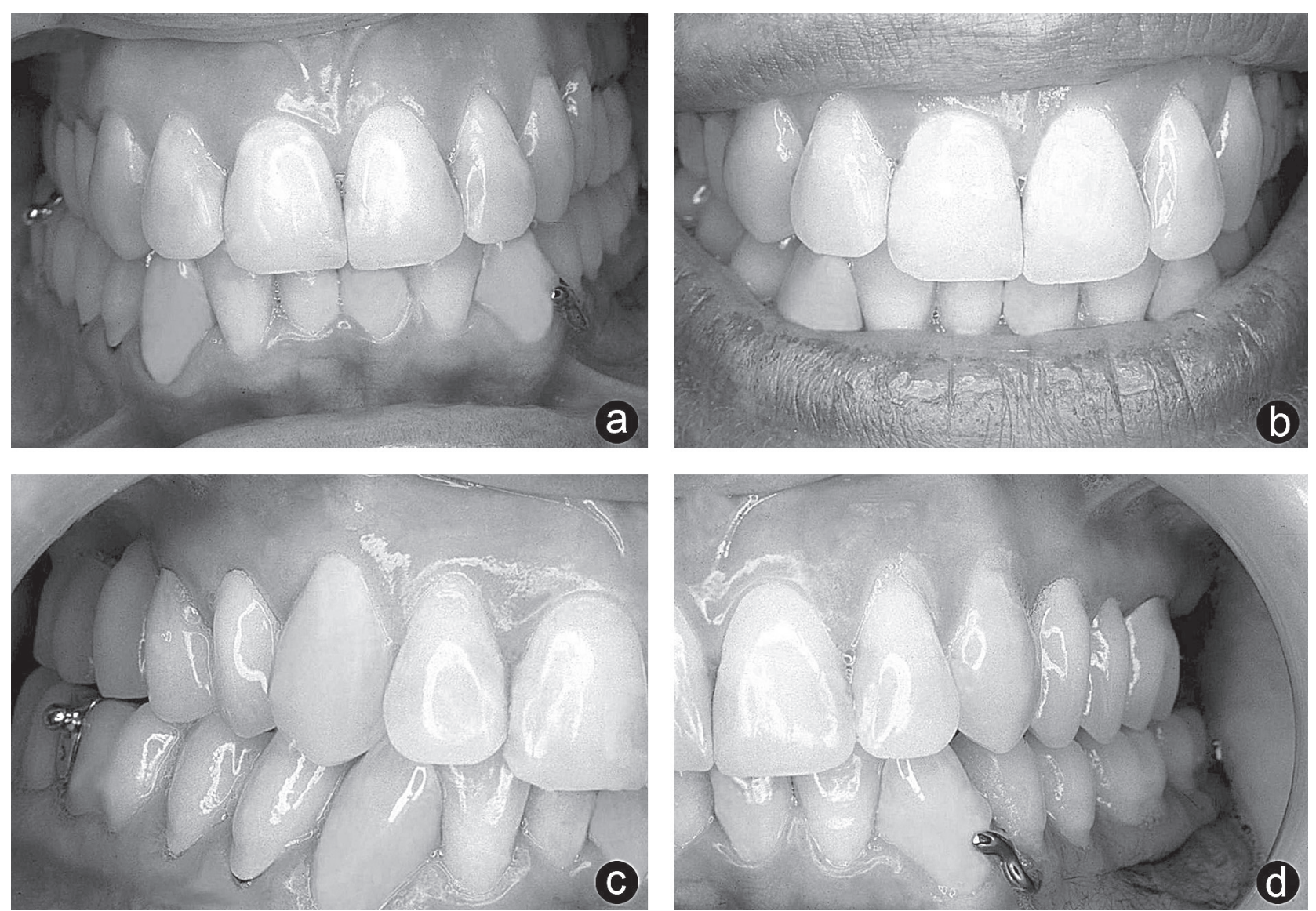

Figure 4. Definitive view of mandibular treatment. A= Note the slight visibility of the RPD retention elements and the pleasant appearance of the characterized denture base; $\mathrm{B}=$ Smiling not exposing the retention elements of the RPD; $\mathrm{C}$ and $\mathrm{D}=\mathrm{Definitive}$ view after completion of the maxillary arch treatment with metal-ceramic crowns. 
attempt to neutralize the fulcrum line established between the geminated retainers from the right side and the left canine (Fig. 3). This was possible because the guide planes prepared on the metal-ceramic crowns ensured the necessary stability by invalidating any vertical or horizontal rotation axis. The use of a characterized acrylic resin base and the arrangement of artificial teeth in harmony with the natural teeth completed the esthetic outocme. The definitive outcome of the clinical situation is shown in Figure 4 after the maxillary rehabilitation.

\section{DISCUSSION}

In this case, the construction of a provisional RPD was essential not only for the esthetic solution of problems generated by the fracture of one of the retainers of the FPD, but also for a correct evaluation of the esthetic and functional aspects. Once the provisional denture was installed, it was possible to evaluate the visibility and final appearance of the definitive denture. Therefore, more than just restore lost teeth, the provisional denture was mandatory for a comprehensive esthetic planning of the prosthetic treatment (19).

In this case, a composite resin cingulum rest was prepared on the canines and the success of the RPDbased treatment was depended on the resistance to wear of the material, which was in close contact with the clasp. During 8 years of case follow-up, it was only necessary to perform realigning and addition of composite resin to the retentive area once.

It is important to consider that, although in Kennedy Class II cases one of the indications is the use of stress breaker, in this case that it was not used because there was no type of damage to the abutment teeth and supporting tissues during the 8 years of follow-up.

It is obvious that the RPD is susceptible to the same wear situations of any denture retained by conventional clasps. The patient was instructed about the importance of adopting bilateral chewing habits. However, she was more comfortable during function on the right side. This fact contributed to preservation of the artificial teeth on the left side that occlude to the metal-ceramic crowns placed on the maxillary arch during a later stage of the oral rehabilitation.

The presence of teeth requiring metal-ceramic crowns in the right mandibular hemi-arch facilitated the treatment plan presented herein. The advantage of this treatment was the relatively fast and satisfactory resolution of the clinical situation, while meeting the expectations and limits imposed by the patient. However, in cases of healthy supporting teeth, the preparation of crowns could be considered a contraindication for this type of treatment.

This case report illustrates that the dentist must be prepared to deal with situations where, for reasons that cannot be managed, the patient does not accept the treatment considered as the most indicated for his/her case. Alternatives must be proposed and the functional and esthetic requirements must be fulfilled in the best possible manner.

\section{RESUMO}

Este artigo relata o caso de uma paciente de 55 anos que apresentava no arco mandibular coroas provisórias insatisfatórias nos prémolares do lado direito e uma prótese parcial fixa de molar a prémolar no lado esquerdo. Os exames clínico e radiográfico revelaram uma fratura do primeiro pré-molar esquerdo que era um retentor da prótese parcial fixa e teve a extração indicada. Inicialmente, as coroas provisórias foram substituídas por novas e uma prótese parcial removível provisória foi confeccionada com resina acrílica e grampos de fio ortodôntico a fim resolver os problemas relacionados à perda da prótese parcial fixa. Considerando a forte demanda estética da paciente, foram discutidas as opções de tratamento protético definitivo. Foi proposta a reabilitação com prótese implanto-suportada uma vez que as condições clínicas do rebordo alveolar se apresentavam adequadas para instalação de implantes e a saúde geral da paciente era excelente. Entretanto, a paciente não concordou com o tratamento proposto, alegando saber de um caso clínico em que houve insucesso na reabilitação por prótese implanto-suportada em um paciente diabético. Ela foi inteiramente informada de que a colocação de implantes era a melhor indicação para seu caso, mas os argumentos não foram suficientes para mudar sua decisão. As possibilidades de tratamento foram apresentadas e a paciente optou por uma prótese parcial removível (PPR) retida a grampos associada com coroas nos dentes pilares. Na seqüência, a PPR provisória foi substituída por uma PPR definitiva. Embora a PPR não tivesse sido a primeira escolha, foram obtidos resultados estéticos e funcionais satisfatórios, superando as expectativas da paciente. Este relato de caso ilustra que o dentista deve estar preparado para enfrentar situações em que, por razões que não possam ser administradas, o paciente não aceite o tratamento considerado mais indicado para seu caso. Alternativas devem ser propostas e as exigências estéticas e funcionais devem ser contempladas da melhor maneira possível.

\section{REFERENCES}

1. King GE. Dual-path design for removable partial dentures. J Prosthet Dent 1978;39:392-395.

2. Jacobson TE, Krol AJ. Rotational path removable partial 
denture design. J Prosthet Dent 1982;48:370-376.

3. De Rossi A, Albuquerque Jr RF, Bezzon OL. Esthetic options for the fabrication of removable partial dentures: a clinical report. J Prosthet Dent 2001;86:465-467.

4. Belles DM. The Twin-Flex clasp: an esthetic alternative. J Prosthet Dent 1997;77:450-452.

5. Coleman AJ, Evans JH. Restoration of posterior edentulous areas when space precludes conventional treatment: a case report. Quintessence Int 1995;26:613-616.

6. Sykora O. Esthetic considerations in the construction of a removable partial denture. Quintessence Int 1994;25:757762.

7. Beaumont AJ Jr. An overview of esthetics with removable partial dentures. Quintessence Int 2002;33:747-755.

8. Frank RP, Brudivik JS, Leroux B, Milgrom P, Hawkins N. Relationship between the standards of removable partial denture construction, clinical acceptability, and patient satisfaction. J Prosthet Dent 2000;83:521-527.

9. Reagan SE, Rold TM. Practical, esthetic options for retention of removable partial dentures: a case report. Quintessence Int 1996;27:333-340.

10. Yunus N, Abdullah H, Hanapiah F. The use of implants in the occlusal rehabilitation of a partially edentulous patient: a clinical report. J Prosthet Dent 2001;86:465-467.

11. Donovan TE, Cho GC. Esthetic considerations with removable partial dentures. J Calif Dent Assoc 2003;31:551-557.
12. Chu $\mathrm{CH}$, Chow TW. Esthetic designs of removable partial dentures. Gen Dent 2003;51:322-324

13. Ancowitz S. Esthetic removable partial dentures. Gen Dent 2004;52:453-459.

14. Marinello CP, Shärer P, Meyenberg K. Resin-bonded etched castings with extracoronal attachments for removable partial dentures. J Prosthet Dent 1991;66:52-55.

15. Piirto M, Eerikainen E, Siirla HS. Enamel bonding plastic materials in modifying the form of abutment teeth for the better functioning of partial prostheses. J Oral Rehabil 1977;4:1-8

16. Quinn DM. Artificial undercuts for partial denture clasps. A technique using composite filling materials. Br Dent $\mathrm{J}$ 1981;151:192-194.

17. Hebel KS, Graser GN, Featherstone JD. Abrasion of enamel and composite resin by removable partial denture clasps. J Prosthet Dent 1984;52:389-397.

18. Markus SJ. Interim esthetic restorations in conjunction with anterior implants. J Prosthet Dent 1999;82:233-236.

19. Bural C, Bayramgurler I, Bayraktar G. Interim removable partial dentures: two cases reports. Gen Dent 2008;56:68-73.

20. La Vere AM, Krol AJ. Selection of a major connector for the extension-base removable partial denture. J Prosthet Dent 2005;94:207-208.

Accepted July 21, 2008 